\title{
Biodegradation of Chlorothalonil Fungicide in Coastal Areas of the Colombian Caribbean Suitable for Banana Crops
}

\author{
Biodegradación del Fungicida Clorotalonil en Áreas Costeras del Caribe Colombiano Adecuadas \\ para Cultivo de Banano
}

\author{
Julián Mauricio Betancourt-Portela ${ }^{1}$, Paola Andrea Bautista Duarte ${ }^{2 *}$, Silvia Narváez Flórez $^{3}$, \\ Juan Pablo Parra Lozano ${ }^{4}$ \\ ${ }^{1}$ Instituto de Investigaciones Marinas y Costeras-INVEMAR, Santa Marta, Colombia \\ ${ }^{2 *}$ Facultad de Ingeniería, Universidad EAN, Bogotá, Colombia \\ ${ }^{3}$ Facultad de Ingeniería, Universidad ECCI, Bogotá, Colombia \\ ${ }^{4}$ Universidad Antonio Nariño, Bogotá, Colombia
}

\begin{abstract}
Chlorothalonil (CHT) is a chlorinated-nitrogen fungicide used in the control of black sigatoka, a disease that affects banana and plantain, has adverse effects on the environment and its metabolites can be toxic. The CHT has been the object of several studies related to its behavior and degradation in the environment; however, few works have been developed in tropical areas, such as the case of the banana zone of Magdalena - Colombia. In addition, it is unknown if the microbial diversity existing in these soils can transform compounds such as CHT, thus these microorganisms can be the basis for the implementation of remediation strategies based on bioaugmentation. In this sense, the present study aims to evaluate the degradation of CHT in soils of a tropical coastal zone, under conditions of natural attenuation and bioaugmentation with native microorganisms. For this purpose, microorganisms capable of growing with CHT as their sole carbon source $\left(10.8 \mathrm{mg} . \mathrm{l}^{-1}\right)$ and tolerating a concentration up to $25 \mathrm{mg} . \mathrm{l}^{-1}$ were isolated and selected from soils in the Magdalena-Colombia banana zone. Subsequently, CHT degradation tests (2000 ng. $\mathrm{g}^{-1}$ ) were performed on experimental plots, with bioaugmentation of native microorganisms and natural attenuation during 35 days, evaluating the growth of microbial populations and the degradation of CHT by gas chromatography associated with a mass spectrometry detector (GC/MS). Because of the microbial selection process, 8 morphotypes were obtained with the ability to grow in CHT as the sole carbon source and tolerate concentrations up to 25 g.l1. The isolates were identified by sequencing the 16S rDNA gene as belonging to the genera Enterobacter, Klebsiella, Pseudomonas and Citrobacter. The CHT degradation tests showed that under bioaugmentation conditions with the native microorganisms selected in the study, a 100\% reduction was achieved after 21 days; while under natural attenuation conditions after 35 days the degradation reached values of $98.5 \%$. The application of bioaugmentation of selected and enhanced bacteria increased the rate of pesticide degradation by 2.5 times, reducing the half-life from 6.2 to 2.5 days. The results demonstrated the effectiveness of the bioaugmentation treatment and that the selected consortium may be useful for bioremediation of banana crops soils contaminated with the fungicide.
\end{abstract}

Keywords: Bioaugmentation, Degradation Kinetics, Chlorothalonil, Selection of Microorganisms and Fungicides

*Corresponding Author.

E-mail: pbautista.d@universidadean.edu.co
How to cite: Betancourt, J. M., Bautista, P. A., Narvaez, S., Parra, J. P., Biodegradation of Chlorothalonil Fungicide in Coastal Areas of the Colombian Caribbean Suitable for Banana Crops, TECCIENCIA, Vol. 13 No. 25, 19-28, 2018 DOI: http://dx.doi.org/10.18180/tecciencia.2018.25.3 


\section{TECCIENCIA}

\section{Resumen}

El Clorotalonil (CHT) es un fungicida clorado-nitrogenado usado en el control de la Sigatoka negra, enfermedad que afecta al banano y el plátano, tiene efectos adversos en el ambiente y sus metabolitos pueden ser tóxicos. El CHT ha sido objeto de diversos estudios relacionados con su comportamiento y degradación en el ambiente, sin embargo, pocos han sido los trabajos desarrollados en áreas tropicales, tal es el caso de la zona bananera de Magdalena - Colombia. Adicionalmente, se desconoce si la diversidad microbiana existente en estos suelos, tienen la capacidad de transformar compuestos como el CHT, de tal manera que puedan ser base para la implementación estrategias de remediación basadas en la bioaumentación. En este sentido, el presente estudio tiene como objetivo evaluar la degradación del CHT en suelos de una zona tropical costera, bajo condiciones de atenuación natural y bioaumentación con microorganismos nativos. Para esto, se aislaron y seleccionaron a partir de suelos de la zona bananera del Magdalena-Colombia, microorganismos con capacidad de crecer con CHT como única fuente de carbono (10.8 mg. $\left.\mathrm{l}^{-1}\right)$ y tolerar una concentración hasta $25 \mathrm{mg} . \mathrm{l}^{-1}$. Posteriormente, se realizaron ensayos de degradación del CHT (2000 ng. $\mathrm{g}^{-1}$ ) en parcelas experimentales, con bioaumentación de microorganismos nativos y con atenuación natural durante 35 días, evaluando el crecimiento de las poblaciones microbianas y la degradación del CHT por cromatografía de gases asociada a un detector de espectrometría de masas (GC/MS). Del proceso de selección microbiana se obtuvieron 8 morfotipos con capacidad de crecer en CHT como única fuente de carbono y tolerar concentraciones hasta 25 g. $1^{-1}$. Los aislamientos fueron identificados por secuenciación del gen 16S rDNA como pertenecientes a los géneros Enterobacter, Klebsiella, Pseudomonas y Citrobacter. Los ensayos de degradación del CHT mostraron que bajo condiciones de bioaumentación con los microorganismos nativos seleccionados en el estudio, se logró una reducción del $100 \%$ tras 21 días; mientras que bajo condiciones de atenuación natural después de 35 días la degradación alcanzó valores del 98.5\%. La aplicación de la bioaumentación de las bacterias seleccionadas y potenciadas aumentó la velocidad de degradación del plaguicida en $~ 2.5$ veces reduciendo el tiempo de vida media de 6.2 a 2.5 días. Los resultados demostraron la efectividad del tratamiento de bioaumentación y que el consorcio seleccionado puede resultar útil para la biorremediación de suelos de plantaciones bananeras contaminados con el fungicida.

Palabras clave: Bioaumentación, Cinética de Degradación, Clorotalonil, Selección de Microorganismos y Fungicidas.

\section{Introduction}

Developing countries such as Colombia, where the economy depends heavily on agricultural production, should seek alternatives to protect crops against the pest outbreaks. The current size of the population demands a large-scale agricultural industry with effective methods of action to meet the demand for food; therefore, the use of pesticides has become a useful tool that has led to an increase in the reserves of raw materials and food in the world [1]; however, this has resulted in an uncontrolled use of pesticides by farmers and a rapid increase in soil contamination, and in some cases water pollution by leaching of pesticide residues

Chlorothalonil (or 2,4,5,5,6-tetrachloroisophthalonitrile; CHT) is a broad-spectrum, non-systemic fungicide for foliar application, used mainly in the control of black Sigatoka in banana and plantain crops; and in bacterial infestations in many crops including inedible ones. The commercial product is synthesized by several multinational companies in different presentations and is marketed under the names of Bravo, Daconil and Termil, among others. Of particular concern is it use in banana plantations where they are applied up to 45 times a year at rates of up to 3.51 of formulated product per hectare [2] [3].
In recent years there have been reports of possible adverse effects on the environment in the southeastern United States from CHT runoff after application in peanuts [4]. The toxicity of CHT was previously studied [5]; for example, it is known that once in the environment, CHT is highly toxic to fish, birds and aquatic invertebrates. In freshwater fish, its toxicity has been observed in concentrations as low as 10.5 $\mu \mathrm{g} . \mathrm{l}^{-1}$, while chronic toxicity can occur at concentrations of $2 \mu \mathrm{g} \cdot \mathrm{l}^{-1}[6]$. For rainbow trout, lethal and sublethal concentration levels at 21 days of 4.9 and $2.3 \mu \mathrm{g} . \mathrm{l}^{-1}$ respectively, have been reported [6].

In humans, $\mathrm{CHT}$ can cause dermatitis, severe irritation of the eyes and skin, and gastrointestinal problems [7]. More recently, an evaluation of the toxicity of pesticides used in Costa Rica concluded that Terbufos and Chlorothalonil are responsible for more than $90 \%$ of human poisoning [8]. Several studies have been published to establish the use and behavior of CHT in the environment, as well as the possible adverse effects associated with its use. Most of the main findings were compiled by the U.S. Environmental Protection Agency [4]. However, these studies were conducted in temperate environments and under conditions that do not apply to more humid and warmer climates such as the tropics. 


\section{TECCIENCLA}

Few studies have been conducted to understand the environmental behavior and use of $\mathrm{CHT}$ and its degradation in tropical environments [13] [14]. There is great uncertainty about the degree of environmental contamination by CHT and the toxic effects on biota, although in several reports have identified the presence of CHT in water bodies draining banana fields [15] [16]. The CHT is considered moderately persistent in soil, although the data presented in the literature show high variability. For example, the half-life in soil/field varies from 4 days to 6 months [17]. In water, the half-life ranges from 0.18 to 8.8 days. Among the most recent studies carried out [18], it is evident that, in soil, CHT disappears rapidly with a half-life of 2.2 - 3.9 days. Nevertheless, the residues of the CTH decomposition can persist for 85 days after application.

Given the problems that CHT represents due to its toxicity and the persistence of its metabolites in the environment, there are different alternatives for remediation. One of the strategies compatible with ecosystems and their resilience process is bioremediation, which emerges as an alternative that uses biodegradative processes, through the use of native microorganisms from the affected area to carry out processes to reduce or eliminate pollutants and thus recover the impacted area [9], as well as transforming toxic substances into less toxic substances or making them harmless to the environment. Bioremediation strategies include natural attenuation, biostimulation, b, bioventilation, bioaugmentation, landfarming, composting and phytoremediation [10], but the three techniques currently predominant are natural attenuation, biostimulation and bioaugmentation.

Bioaugmentation is related to the addition of microorganisms in places where degrading populations are not present or where the levels found are very low. This technique has not always proved to be effective because introduced microorganisms have to compete with indigenous populations [11]. On the other hand, biostimulation is a technique that provides bacterial communities with a favorable environment in which the degradation of the contaminant can be effective, for which the area to be bioremediated is supplied with nutrients, cosubstrates or oxygen, according to the specific requirements of each area [12]. This addition of elements generates costs, which represents an economic disadvantage compared to other alternatives.

For this reason, the present study aims to evaluate the degradation of CHT in soils of a tropical coastal area, under conditions of natural attenuation and bioaugmentation with native microorganisms, thus, to propose an effective strategy that allows to reduce the impact generated by pesticides currently used to fumigate extensive banana and plantain crops nearby the Colombian Caribbean Sea.

\section{Materials and methods}

\subsection{Study area}

The Magdalena Banana Zone is in northern Colombia between the eastern margin of the Ciénaga Grande de Santa Marta and the foothills of the Sierra Nevada de Santa Marta; it is located between $10^{\circ} 46^{\prime} 00^{\prime \prime} \mathrm{N}$ and $74^{\circ} 8^{\prime} 00^{\prime \prime} \mathrm{W}$ and includes part of the municipality of Ciénaga, and the municipalities Zona Bananera and Fundación. It has about 11,800 hectares dedicated to the cultivation of bananas with an annual production of approximately 430,050 tons. It is characterized by having clay soils, the annual precipitation can fluctuate between $400 \mathrm{~mm}$ and 1,000 $\mathrm{mm}$ per year, causing aerial fumigation cycles to change according to the time of year and requires manual reinforcement. In the Banana Zone, around 800,000 liters of liquid and 3,500,000 $\mathrm{kg}$ of pesticides are applied in solid form to its crops, from which, through runoff, erosion and poor application, these chemical substances can reach water sources, affecting the development of flora and fauna, as well as generating bioaccumulation or biomagnification of the contaminant and impacting the food chain [19].

In the area, a total of five sites were selected for sampling, four of which were farms that have been dedicated to banana cultivation for more than 10 years, under traditional agriculture with manual and aerial fumigation of pesticide, in the process of applying good agricultural practice; the other sampling point was the airstrip, from where the planes take off for fumigation. It is important to note that the farms are located near the Seville River which flows into the Ciénaga Grande de Santa Marta.

\subsection{Sampling}

Soil samples for the selection of microorganisms and soil characterization for degradation tests were collected $5 \mathrm{~cm}$ from the surface, because this is where the soil strongly absorbs pesticides such as CHT. In total, 10 subsamples were collected in each site, which were mixed together to form a composite sample from each sampling point. For this purpose, a zig-zag layout was made with a distance between vertices of approximately $40 \mathrm{~m}$, with a perpendicular path to the orientation of the crop lots in the farms and in this way, cover as much land as possible. Soil sampling points were located $1.5 \mathrm{~m}$ from each plant in the area of maximum exposure to aerial fumigation.

All samples were collected in aluminum containers treated with solvents and labeled, they were refrigerated at $4^{\circ} \mathrm{C}$ and taken to the Unit of Marine Environmental Quality Laboratories of the Institute of Marine and Coastal Research (Instituto de Investigaciones Marinas y CosterasINVEMAR). 


\section{TECCIENCLA}

They were then stored frozen at $-20^{\circ} \mathrm{C}$ for a maximum time of 14 days for physical-chemical analysis, while samples for microbiological test were analyzed immediately.

\subsection{Isolation and selection of morphotypes}

The microorganisms used in the degradation process were isolated by means of serial dilutions and seeding on surface in plates of nutrient Agar (Merck) from soil samples from the five sampling points located in the banana zone [20]. The boxes were incubated at $30 \pm 0.5^{\circ} \mathrm{C}$ for a period of 48 hours. Afterwards, the morphotypes with differential macroscopic characteristics (color, shape, size, elevation) were chosen to be selected for their ability to use the CHT pesticide as their sole carbon source.

To perform the selection of the morphotypes, the Replica Plating method [24] was used in a minimal medium of salts supplemented with CHT at a concentration of $10.8 \mathrm{mg} . \mathrm{L}^{-1}$ as the only carbon source. Four successive passes were made for each morphotype, every 4 days until completing 16 days. The purpose of the successive passes is to deplete the metabolic reserves and force the microorganisms to use the nutritional sources provided to them, being in this case the pesticide the only source of carbon. The liquid medium [25] was used, with the modification of using $\left(\mathrm{NH}_{4}\right)_{2} \mathrm{HPO}_{4}$ instead of $\mathrm{NH}_{4} \mathrm{NO}_{3}$ and $\mathrm{Fe}_{2}\left(\mathrm{SO}_{4}\right)_{3} .7 \mathrm{H}_{2} \mathrm{O}$ instead of $\mathrm{Fe}_{2}\left(\mathrm{SO}_{4}\right)_{3}$; the use of this minimal medium of salts (MMS) was due to the fact that CHT contains chlorine and for the selection of bacteria it is necessary to use a culture medium that does not include this element. After incubation the growth of the isolated strains was recorded and macroscopically and microscopically characterized according to the characterization guide [22] and kept at $-4^{\circ} \mathrm{C}$ and $-70^{\circ} \mathrm{C}$.

Subsequently, an approximation to the minimum inhibitory concentration (MIC) was carried out. For this purpose, the Replica Plating technique was used again [24] increasing Chlorothalonil in concentrations of $15,20,25 \mathrm{mg} . \mathrm{L}^{-1}$ in solid medium [21]. "The boxes were incubated at $30^{\circ} \mathrm{C} \pm 0.5^{\circ} \mathrm{C}$ for 2 days. At the end of the incubation time, the result was read by absence/presence of microbial growth against each concentration. The objective of this test was to determine which isolates have the greatest tolerance capacity against CHT, and therefore greater advantages to form a consortium to be used in bioremediation. The crops with greater tolerance were selected for field degradation trials.

\subsection{Identification of morphotypes}

The morphotypes selected in the Replica Plating test were identified by sequencing the $16 \mathrm{~S}$ rDNA gene. For this aim, each morphotype was incubated for 18 hours at $30 \pm 0.5^{\circ} \mathrm{C}$ in Luria Bertani medium with constant agitation.
Of the culture, $25 \mu \mathrm{L}$ were taken and placed in a $1.5 \mathrm{ml}$ Eppendorf tube. This was carried to a water bath at a temperature of $80^{\circ} \mathrm{C}$ for 15 minutes, followed by centrifugation at $14,000 \mathrm{rpm}$ for $1 \mathrm{~min}$ at $4^{\circ} \mathrm{C}$; of the supernatant $0.9 \mu 1$ was taken as template.

For the amplification of the 16S rDNA region, reactions with a final volume of $25 \mu 1$ were prepared; the primers to amplify were $27 \mathrm{f}$ ( $5^{\prime}$-AGAGTTTGATCCTCCTGGGCTCAG-3') and 1492r (5'- ACGGGCTACCTTGTGTACGACTT-3') [26]. Final concentrations were $0.2 \mu \mathrm{M}$ for each primer, $0.2 \mu \mathrm{M}$ of each dNTPs, $2 \mathrm{U}$ of taq (invitrogen), $1 \mathrm{X}$ of PCR buffer and $2.5 \mathrm{mM}$ of $\mathrm{MgCl}_{2}$. The reactions were taken to the iCycler (BioRad) thermal cycler with an initial denaturing at $94^{\circ} \mathrm{C}$ for $5 \mathrm{~min}$, followed by 30 cycles at $94^{\circ} \mathrm{C}$ for $30 \mathrm{~s}, 55^{\circ} \mathrm{C}$ for $30 \mathrm{~s}, 72^{\circ} \mathrm{C}$ for $30 \mathrm{~s}$, with a final extension at $72^{\circ} \mathrm{C}$ for 7 $\min$.

The PCR products were analyzed by $0.7 \%$ (w/v) agarose electrophoresis and after checking the concentration of the fragment the Wizard ${ }^{\circledR}$ SV Gel and PCR Clean-Up System (Promega) were used for the purification of PCR products. The BigDye ${ }^{\circledR}$ Terminator v3.1 Cycle Sequencing Kit (Applied BioSystems.) and the ABI PRISM ${ }^{\circledR} 310$ Genetic Analyzer (Applied BioSystems) were used for sequencing. For the analysis of the 16S rDNA sequences, each sequence obtained was compared with the National Center for Biotechnology Information GenBank database using the BLAST tool [27].

\subsection{Formulation of bacterial pools}

For the development of the bioaugmentation tests, the selected and identified bacteria were prepared in the laboratory for field use. The initial stage consisted in the elaboration of the inoculum of each strain belonging to the bacterial pool in a concentration of approximately $10^{7}$ cells. $\mathrm{ml}^{-1}$. For this aim, each was grown separately in a nutrient agar at $30^{\circ} \mathrm{C} \pm 0.5^{\circ} \mathrm{C}$ for $24-48$ hours. After this period a colony was taken and placed in a $100 \mathrm{ml}$ Erlenmeyer with MMS supplemented breeding ground with $25 \mathrm{mg} . \mathrm{L}^{-1}$ of CHT, kept in constant agitation at $30^{\circ} \mathrm{C}$ for 48 hours, until a approximate concentration of $10^{7}$ cells. $\mathrm{mL}^{-1}$ was obtained [28]. At the end of this time, the inoculum of each microbial strain was mixed in an Erlenmeyer flask, which was kept at room temperature under aseptic conditions until transported to the field. Each liter of the inoculant was diluted in $5 \mathrm{~L}$ of water for application [28].

\subsection{Chlorothalonil Degradation Tests}

The degradation was evaluated in a field test. For which, one of the farms assessed was selected, considering the number of isolated morphotypes resistant to CHT, as well as the permission and availability for the development of the trials. 


\section{TECCIENCLA}

On the selected farm, a composite soil sample was collected, which was characterized by determining the physical and chemical properties of the soil as shown in Table 1.

For the assembly of the degradation tests, six beds of area $1.5 \times 0.7 \mathrm{~m} 2$ were installed, insulated at the bottom with plastic membrane to prevent leaching. Two treatments were evaluated, treatment 1 (T1) consisted of bioaugmentation with the selected native microorganisms and treatment 2 (T2) consisted of uninoculated soil, in which the natural attenuation process was evaluated.

All trials were conducted in triplicate for 35 days. The test beds were added with the pesticide at the concentration recommended by the manufacturer for dosing into banana crops (2000 ng.g-1). The soil moisture was adjusted to $60 \%$ of the field capacity and maintained by adding water every two days. The soil samples to determine the concentration of CHT were collected in triplicate after 0, 4, 7, 14, 21, 29 and 35 days. Simultaneously, the concentration of microorganisms was analyzed on $0,4,7,14,21$ days through surface sowing in nutritive agar, incubated at $30 \pm 0.5^{\circ} \mathrm{C}$ for 48 hours. The field measurements were used to calculate the CHT loss rate under tropical conditions. The degradation was calculated as an exponential decay in a first-order kinetics of form:

waste $=$ waste $\left(t_{0}\right) \exp (k t)$.

Here $k$ is the degradation constant and $t$ is the time in days after application. The degradation rate $k$ and the correlation coefficient $\left(r^{2}\right)$ were calculated with a regression analysis of the concentration vs day for each treatment, from the least squares analysis the slope was estimated as the value of $k$; and the half-life in days was calculated as $(k-1) \ln (0.5)$. The slopes of each treatment, as well as the calculated half-life, were compared in an analysis of variance using the statistical software Infostat [29].

The CHT extraction procedure consisted of a solid-liquid cold extraction. Ten grams (10 g) of soil were used for extraction with a 1:1 dichloromethane/acetone mixture, by stirring for 10 minutes. Of the solvent, $100 \mathrm{ml}$ was used divided into three successive extractions, the first of $50 \mathrm{ml}$ and the remaining of $25 \mathrm{ml}$. After extraction, the organic phase was decanted, and the solvent was separated by filtration in a glass funnel conditioned with fiberglass and 10 $\mathrm{g}$ of sodium sulfate. Finally, the three extracts were collected in a boiling flask and concentrated in a rotary evaporator, preventing the water bath temperature from exceeding $34^{\circ} \mathrm{C}$ according to the guidelines defined in the guide for pesticide analysis [30]. The extraction process was evaluated using PCB-103 as the recovery standard, which was added prior to the first extraction.
Table 1 LS-Fit to $H_{0}$ data.

\begin{tabular}{|c|c|}
\hline Determination & Analytical Technique Used \\
\hline Granulometry & $\begin{array}{c}\text { Gravimetric method (dispersion in sodium } \\
\text { hexametaphosphate and screening in different } \\
\text { sieves; Dewis and Freitas (1984)) }\end{array}$ \\
\hline $\mathrm{pH}$ & $\begin{array}{c}\text { Electrometer measurement with WTW pH-315 } \\
\text { portable probe (sediment dilution 1:2, IGAC, 1990; } \\
\text { Standard Methods No. 4500-H+; APHA, 2005) }\end{array}$ \\
\hline $\begin{array}{c}\text { Volatile } \\
\text { organic } \\
\text { matter } \\
\text { (volatile MO, } \\
\text { mg/g) }\end{array}$ & Gravimetric method, calcination at 550 ${ }^{\circ} \mathrm{C}$ \\
\hline $\begin{array}{c}\text { Oxidizable } \\
\text { organic } \\
\text { matter (MO } \\
\text { oxy, mg/g) }\end{array}$ & $\begin{array}{c}\text { Cold digestion with potassium dichromate, Walkey } \\
\text { and Black method (IGAC, 1990) }\end{array}$ \\
\hline $\begin{array}{c}\text { Total } \\
\text { Kjeldahl } \\
\text { Nitrogen } \\
\text { (TKN) }\end{array}$ & Acid digestion (IGAC, 1990) \\
\hline $\begin{array}{c}\text { Total } \\
\text { Phosphorus } \\
\text { (P-Total, } \\
\left.\text { mg.g } \text { g }^{-1}\right)\end{array}$ & $\begin{array}{c}\text { Acid extraction and determination of } \\
\text { orthophosphates by spectrophotometry using the } \\
\text { ascorbic acid method (Standard Methods 4500-P; } \\
\text { APHA, 2005) }\end{array}$ \\
\hline $\begin{array}{c}\text { Interchangeab } \\
\text { le potassium } \\
\text { (ppm) }\end{array}$ & $\begin{array}{c}\text { By saturation of the soil and determination of the } \\
\text { retained potassium. (López and López, 1978) }\end{array}$ \\
\hline $\begin{array}{c}\text { Cation } \\
\text { exchange } \\
\text { capacity } \\
\left.\text { (cmol. Kg }{ }^{-1}\right)\end{array}$ & $\begin{array}{c}\text { By soil saturation and determination of retained } \\
\text { cations. (López and López, 1978). }\end{array}$ \\
\hline
\end{tabular}

\subsection{Analytical determinations}

The determination was performed by gas chromatography associated with a mass spectrometry detector (GC/MS) in a Shimadzu QP-2010S device operated in Selective Ion mode (SIM); with a spitless injection system and capillary column of $30 \mathrm{~m}$ length $\times 0.25 \mathrm{~mm}$ internal diameter and a liquid phase of 5\% diphenyl-95\% dimethyl polysiloxane (HP-5) of $0.25 \mu \mathrm{m}$ thickness.

High purity helium at $1.0 \mathrm{ml} \mathrm{min}{ }^{-1}$, injector temperature of $275^{\circ} \mathrm{C}$ and interface of $300^{\circ} \mathrm{C}$ was used as carrier gas; the temperature program in the furnace was: $60^{\circ} \mathrm{C}(1 \mathrm{~min})$ at $12^{\circ} \mathrm{C} \mathrm{min}^{-1}$ up to $150^{\circ} \mathrm{C}(0 \mathrm{~min}), 7^{\circ} \mathrm{C} \mathrm{min}^{-1}$ at $230^{\circ} \mathrm{C}(3 \mathrm{~min})$; $5^{\circ} \mathrm{C} \min ^{-1}$ at $300^{\circ} \mathrm{C}(4 \mathrm{~min})$.

Table 2 CHT- tolerant morphotypes.

\begin{tabular}{cccc}
\hline $\begin{array}{c}\text { Sampling } \\
\text { point }\end{array}$ & UFC.g $^{-1}$ & $\begin{array}{c}\text { No Total } \\
\text { Morphotypes }\end{array}$ & $\begin{array}{c}\text { CHT-tolerant } \\
\text { morphotype } \\
\left(10.8 \text { mg.L }^{-1}\right)\end{array}$ \\
\hline Farm 1 & $30 \times 10^{5}$ & 15 & 5 \\
Farm 2 & $25 \times 10^{5}$ & 15 & 1 \\
Farm 3 & $25 \times 10^{5}$ & 19 & 7 \\
Farm 4 & $60 \times 10^{5}$ & 15 & 5 \\
Track & $40 \times 10^{5}$ & 14 & 8 \\
\hline
\end{tabular}




\section{TECCIENCIA}

Table 3 Identification of isolated morphotypes capable of tolerating or degrading pesticides in the banana area.

\begin{tabular}{cc}
\hline Morphotype & Species (identified) \\
\hline FP6 & Klebsiella FP6 sp. \\
FP7 & Klebsiella FP7 sp. \\
FP10 & Pseudomonas FP10 sp. \\
FP14 & Pseudomonas FP14 sp \\
FP16 & EnterobacterFP16 sp. \\
FP19 & Citrobacter FP19 $\mathrm{en}$ \\
FP21 & Enterobacter FP21 sp. \\
FP22 & Enterobacter FP22 sp. \\
\hline
\end{tabular}

The quantification of the extract was performed with an internal standard - 2,4,5,6-tetrachloro-m-xylene (TCMX), which was added to the chromatography vial prior to injection. Chromatograms were also obtained in SCAN mode in the range of 50 to $550 \mathrm{~m} / \mathrm{z}$ to identify the formation of metabolites.

The results were subject to quality control procedures. Reagent blanks and a series of fortified samples with known quantities of the analytes were included in each batch of analyses. The limit of detection (LD) was calculated at 3.0 ng. $\mathrm{g}^{-1}$. The differences between duplicates for analytes with concentration higher to LD were on averaged $17 \%$. The analysis of fortified targets showed average recoveries of $97 \%$ and the fortified samples showed average recoveries of $98 \%$.

\section{Results and discussion}

\subsection{Isolation and selection of morphotypes}

From the serial dilutions and sowing in different agars, the isolation of 62 morphotypes from the different sampling points was achieved, where the total heterotrophic concentrations were in the order of 10-6 CFU.g-1 (Table 2). Of these 62 isolations, 26 isolates were obtained after using the Replica Plating method that were able to use CHT in a concentration of $10.8 \mathrm{mg}$.L-1 as the only carbon source after four successive passes, obtaining the highest number of morphotypes from the track. Finally, only 8 were able to tolerate the concentration of $25 \mathrm{mg}$.L-1 evaluated. None of the microorganisms corresponded to possible pathogens described for banana cultivation, which makes isolated strains more promising for application near cultivated areas without endangering production. Strains belonging to the mixed culture showed a growth at 25 mg.L-1 of Chlorothalonil and therefore they were selected for biodegradation studies. In the present study, the CHT was the only source of carbon/energy during the enrichment and selection of organisms, in order to isolate organisms that could tolerate it. A simple and reliable method, Replica Plating, was used in the selection experiments.
It provided a wide range of CHT concentrations and was able to help characterize the set of morphotypes and was successful in obtaining strains with a high potential to tolerate and degrade CHT.

\subsection{Degradation tests}

\subsubsection{Physico-chemical characterization of the soil of the experimental plots}

The characterization of the physicochemical properties of the soil is presented for the selected farm where the degradation tests were carried out (Table 4). The $\mathrm{pH}$ obtained was 6.96, which according to what is reported [31] is in the range necessary for the activities of most bacteria in the soil (5.5-8.8) and close to the optimal value of 6.5.

The content of oxidizable organic matter was high (1.4\%) which favored the growth of microorganisms, since this fraction of organic matter represents the easily degradable. The content of volatile matter was $\sim 5.0 \%$ and the C:N:P ratio was calculated at 279:28:1 close to the optimal ratio described by several authors $(100: 10: 1 ;[32])$, which also promotes bacterial growth.

The soil texture was classified as silty loam, with approximately $50 \%$ sand and silt. The above characteristics favored the performance of the degradation test without the need to apply amendments to the soil and explains why the biostimulation process was not considered as one of the alternatives tested, which would lead to additional costs in the future applications of the isolated microorganisms' consortium.

\subsubsection{Monitoring the growth of microorganisms in bioaugmentation and natural attenuation tests}

On the other hand, Figure 1 shows the growth kinetics of microbial populations in the presence and absence of CHT. The pesticide metabolism is detected by an increase in the number of colony-forming units over time. The two treatments showed rapid initial growth, however, in the bioaugmentation treatment (T1), the growth seems to be suppressed after the fifth day, a situation that has been documented in other bioaugmentation processes because the introduced microorganisms must compete with the native populations, which are better adapted to the environmental conditions [11].

Nevertheless, after day 20, the growth of microorganisms in $\mathrm{T} 1$ increased and was matched by the natural attenuation treatment (T2). This increase coincided with the disappearance of the CHT after 14 days. This is an indication that the microorganisms decreased while consuming the carbon source of CHT until day 21 while adapting to other carbon sources. 
Table 4 Physico-chemical characteristics of the soil of the experimental plots used in Chlorothalonil degradation studies in a banana plantation in Magdalena, Colombia

\begin{tabular}{|c|c|}
\hline Parameter & Farm soil \\
\hline Granulometry $^{\text {at }}$ & silty loam \\
\hline$<63 \mu \mathrm{m}(\%)$ & $51.2-55.2$ \\
\hline $63 \mu \mathrm{m}(\%)$ & $17.3-19.5$ \\
\hline $125 \mu \mathrm{m}(\%)$ & $18.6-19.2$ \\
\hline $250 \mu \mathrm{m}(\%)$ & $5.3-6.1$ \\
\hline $500 \mu \mathrm{m}(\%)$ & $1.9-2.1$ \\
\hline $1000 \mu \mathrm{m}(\%)$ & $0.9-1.2$ \\
\hline $2000 \mu \mathrm{m}(\%)$ & $0.0-0.8$ \\
\hline $\mathrm{pH}^{\mathrm{b}}$ & $6.96(0.73)$ \\
\hline Density $(\mathrm{g} / \mathrm{L})$ & $2,26(0.22)$ \\
\hline $\begin{array}{l}\text { Oxidizable organic matter } \\
(\mathrm{mg} / \mathrm{g})^{\mathrm{c}}\end{array}$ & $13,80(2.48)$ \\
\hline Volatile organic matter $(\mathrm{mg} / \mathrm{g})$ & $49,64(10.12)$ \\
\hline Total nitrogen $(\mu \mathrm{g} / \mathrm{g})$ & $1792.8(374.1)$ \\
\hline Total phosphorus $(\mu \mathrm{g} / \mathrm{g})$ & $283.9(203.6)$ \\
\hline $\mathrm{C} / \mathrm{N}$ & $9.42(2.99)$ \\
\hline $\mathrm{P} / \mathrm{N}$ & $27.74(27.1)$ \\
\hline $\mathrm{P} / \mathrm{L}$ & $279.02(313.0)$ \\
\hline $\mathrm{C} / \mathrm{N} / \mathrm{P}$ & $279: 28: 1$ \\
\hline $\begin{array}{l}\text { Interchangeable potassium } \\
(\mathrm{ppm})\end{array}$ & $221.61(171.4)$ \\
\hline $\mathrm{CIC}(\mathrm{cmol} / \mathrm{Kg})$ & $12.0(3.1)$ \\
\hline
\end{tabular}

a. Classification of soils according to [33].

b. Soil dilution 1:2[34] (IGAC, 1990).

c. Cold digestion with potassium dichromate, Walkey and Black Method [34]

In T2, native organisms were using other sources of carbon due to the availability of carbon and additional nutrients from the environment, which is why it remains approximately constant.

\subsection{Degradation of Chlorothalonil}

The biodegradation of Chlorothalonil technical quality was measured under field conditions, in a bioaugmentation treatment with microorganisms (T1) and in a natural soil without bioaugmentation (T2).

Gas chromatography was used to monitor the disappearance of Chlorothalonil and the formation of different metabolites. At 21 days of the trial, it revealed the disappearance (nondetection) of CHT from the soil to which the bacterial pool (T1) was applied, while the treatment equivalent to natural attenuation (T2) still had concentrations of 30.9 $\pm 5.1 \mathrm{ng} . \mathrm{g}-1$ (Figure 2).
Table 5 Percentage of pesticide degradation over time (T1: treatment with the addition of native microorganisms; and T2: natural attenuation). Different letters indicate significant differences $(\mathrm{p}<0.05)$.

\begin{tabular}{ccc}
\hline $\begin{array}{c}\text { Time } \\
\text { (days) }\end{array}$ & $\begin{array}{c}\text { of CHT } \\
\text { degraded } \\
(\mathrm{T} 1)\end{array}$ & $\begin{array}{c}\text { of CHT } \\
\text { degraded } \\
(\mathrm{T} 2)\end{array}$ \\
\hline 0 & $0.0^{\mathrm{F}}$ & $0.0^{\mathrm{F}}$ \\
4 & $56.8^{\mathrm{E}}$ & $66.4^{\mathrm{D}}$ \\
7 & $88.1^{\mathrm{B}}$ & $71.0^{\mathrm{C}}$ \\
14 & $97.7^{\mathrm{A}}$ & $79.4^{\mathrm{B}}$ \\
21 & 100.0 & $95.8^{\mathrm{A}}$ \\
29 & & $96.5^{\mathrm{A}}$ \\
35 & & $98.5^{\mathrm{A}}$ \\
\hline
\end{tabular}

In the natural attenuation treatment (T2) the concentration of CHT persisted for a longer interval of time. After 35 days of the test, $98.5 \pm 0.2 \%$ was degraded, whereas in $\mathrm{T} 1$ this level of degradation was reached in 14 days (Table 5).

This situation is due to the treatment applied (T1) was a bioaugmentation of the naturally present bacteria of the site, and probably they were the same as those that appear in T2, so they will also consume the pesticide reducing its concentration. However, they then differ because the bioaugmented bacteria are also previously biostimulated by screening tests in the laboratory to tolerate and use the pesticide as a carbon source.

This proved the effectiveness of the bioaugmentation treatment by increasing the rate of degradation approximately 2.5 times compared to natural attenuation. The degradation was particularly rapid during the first four days after the application of the fungicide, with losses of up to $66.4 \pm 4.36 \%$ of the initial concentration.

The CHT continued to degrade rapidly during the first week after application, following a first-order exponential decay $\left(r^{2}>0.90, p<0.05\right.$; Table 6). After this period the CHT was slowly degraded until it was not detectable in the $\mathrm{T} 1$ treatment at 21 days. In the case of natural attenuation it reached concentrations of $30.9 \pm 5.1 \mathrm{ng} . \mathrm{g}-1$ after 35 days of application (Figure 2).

These results were in accordance with the background concentration of $12.8 \pm 2.3 \mathrm{ng} . \mathrm{g}-1$ measured in a banana crop to which the fumigation was removed for four months [18].

The half-life observed in this study was lower than the 4 to 90 days commonly reported in the literature for temperate environments [4]. 


\section{TECCIENCIA}

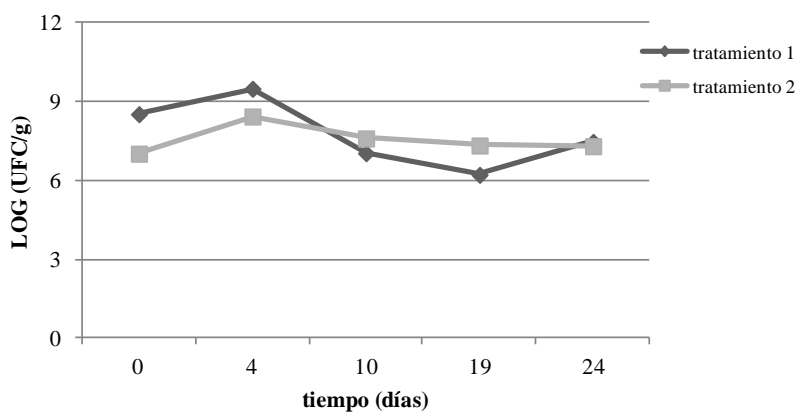

Figure 1 Counting of micro-organisms in the presence of CHT (2000 ng. g $^{-1}$ ) T1: treatment with the addition of native micro-organisms; and T2: natural attenuation.

The present results were more consistent with studies conducted [35] on the degradation of CHT after application to peanut crops in Georgia, USA, where they established a half-life of $<1$ to 3.5 days in laboratory incubated soils at $30^{\circ} \mathrm{C}$; and in banana plantations in Costa Rica where they recorded a half-life of 2.2 days [18].

Studies carried out on the degradation of CHT in tropical soils in Brazil [14], showed half-lives between 0.4 to 13 days depending on the type of soil. It is shorter in soils with a high content of organic carbon, due to the rapid formation of bonds between the residues and the soil and the increase in microbial degradation. The formation of bonds with the soil is of environmental interest, because strongly bonded waste is less likely to be degraded or transported. Therefore, the residues linked to the matrix should not be considered in the result of the degradation of the compound, in addition, further research is needed to evaluate the long-term effects of the frequent application of CHT on these soil-binding mechanisms [14].

In this study it was established that although the natural attenuation, achieved a significant reduction, after one month of application of the pesticide, there were still traces of CHT in the soil. Since there is no information available on reference levels in environmental legislation in soils, it is not possible to qualify the concentrations recorded, nevertheless, by the studies carried out in irrigation channels [36], the concentrations found in the range of 30 - 94 ng.g-1 are considered high and typical of an area with strong agricultural activity. This indicates that the natural attenuation is not enough to degrade the pesticide released into the soil, even more, considering that the fumigation cycles in banana plantations are 15 to 20 days, which would not achieve self-purification.

\subsection{Mineralization of Chlorothalonil}

The microbial metabolism of CHT produces the formation of several intermediates or metabolites before its complete mineralization.

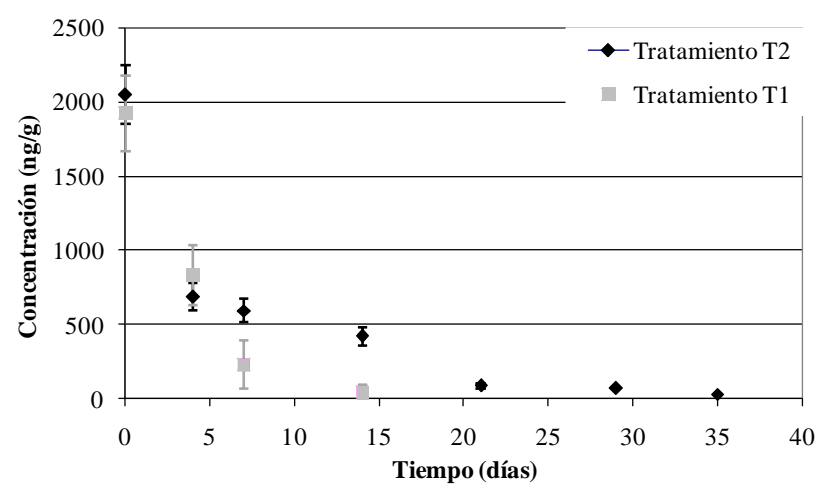

Figure 2 Decrease of the Chlorothalonil concentration in soil of a banana farm due to biodegradation. T1: treatment with the addition of native microorganisms; and T2: natural attenuation.

In this study the formation of six metabolites was observed (Figure 2), however, only one of them, the Diuron, was identified. It has been reported that CHT is metabolized in soil mainly at 4-hydroxy-2,5,6-trichloroisophthalonitrile, a more toxic and persistent metabolite that can cause inhibition of degradation due to its toxicity to microorganisms [37]. Nevertheless, through the GC/MS used it was not possible to identify it.The increase in Diuron was observed from days 4 to 7 and then decreased and was not detected after 21 days (Figure $3 \mathrm{~B}$ and C). From day 7 onwards, another unidentified metabolite began to emerge and then disappears at day 21 (Figure $3 \mathrm{C}$ ), according to its spectrum, its structure must be of higher molecular weight than CHT, suggesting possible oxidation or esterification of the - $\mathrm{CN}$ bonds. Between day 21 and 29 a series of metabolites of lower molecular weight have been formed and begin to be degraded (represented by the decrease in the size of chromatographic peaks, Figure $3 \mathrm{D}$ and E).

The determination of Diuron as a metabolite of CHT degradation in soils is an important step to understand the dynamics of this compound, since some investigations recorded the detection of Diuron in runoff waters to the Caribbean Sea, however, the product is not used by the banana producers' association [16].

In other studies [38], 10 degradation metabolites were identified using GC/MS and LC/MS analyses, including: 4hydroxy-2,5,6-trichloroisophthalonitrile; 1,3-dicarbamoyl2,4,5,6-tetra chlorobenzene; 2,5,6-trichloro-4-methoxy isophthalonitrile; 1-carbamoyl-3-cyano-4-hydroxy 2,5,6trichlorobenzene; 2,4,5-trichloroisophthalonitrile; 2,4,5,6trichloroisophthalonitrile-4-(methylthio)isophthalonitrile; isophthalonitrile; Pentachloronitrobenzene; 5-hydroxydicambit; and 3-(3,4-dichlorophenyl) ${ }^{-1}$,1-dimethylurea (or Diuron). 


\section{TECCIENCIA}

Table 6 Kinetic parameters of the exponential decay of Chlorothalonil in the soil of a banana plantation in Magdalena - Colombia. After application of Bravo 720® $(k$ $=$ degradation constant; $t_{1 / 2}=$ half-life; $r^{2}=$ correlation coefficient and $\mathrm{SD}=$ standard deviation).

\begin{tabular}{lccccc}
\hline \multicolumn{1}{c}{ Treatment } & $\begin{array}{c}\text { Initial } \\
\text { conc. } \\
\left(\mathrm{ng.g}^{-1}\right)\end{array}$ & $\begin{array}{c}\text { SD of } \\
\text { initial conc. }\end{array}$ & $\begin{array}{c}k \\
\left(\mathrm{~d}^{-1}\right)\end{array}$ & $r^{2}$ & $\begin{array}{c}t_{1 / 2} \\
(\mathrm{~d})\end{array}$ \\
\hline $\begin{array}{l}\text { Bioaugmen- } \\
\text { tation with } \\
\text { bacteria (T1) }\end{array}$ & 1921.5 & 258.1 & 0.28 & 0.986 & 2.5 \\
$\begin{array}{l}\text { Natural } \\
\text { attenuation } \\
(\mathrm{T} 2)\end{array}$ & 2045.2 & 196.4 & 0.11 & 0.955 & 6.2 \\
\hline
\end{tabular}

Identification of species is complex because some of these compounds are highly polar and thermolabile and cannot be determined by gas chromatography because they decompose, have low volatility or require additional derivatization processes to identify them [38].

\section{Conclusions}

Eight native microorganisms with a potential to tolerate and degrade CHT were obtained, which makes them suitable for use in bioaugmentation strategies due to their ability to remove this persistent organic compound. Molecular identification of the microorganisms isolated from the plantation soil facilitated their safe application since it was ruled out that they were pathogenic micro-organisms for banana crops.

The concentrations of CHT and its metabolites were detected in the soil until day 35 after the application of the fungicide to the natural attenuation assays, while, for the bioaugmentation assay, concentrations of CHT were detected until day 21. The results showed that the biodegradation process was adjusted to first-order kinetics $\left(r^{2}>0.9\right)$.

Moreover, the application of bioaugmentation of selected and enhanced bacteria increased the rate of pesticide degradation by approximately 2.5 times, reducing the halflife from 6.2 to 2.5 days, which demonstrated the effectiveness of bioaugmentation treatment and that the use of native bacteria can reduce the persistence of CHT in banana plantation soils by increasing this speed.

The above reveals that bioaugmentation processes with native microorganisms can be part of the management of leaching and runoff of soil pesticides, offering an efficient and low-cost method for decontamination of these, the results represent a high scientific impact since there are few studies in the coastal zone of the Colombian Caribbean that can be used with biotechnological potential.

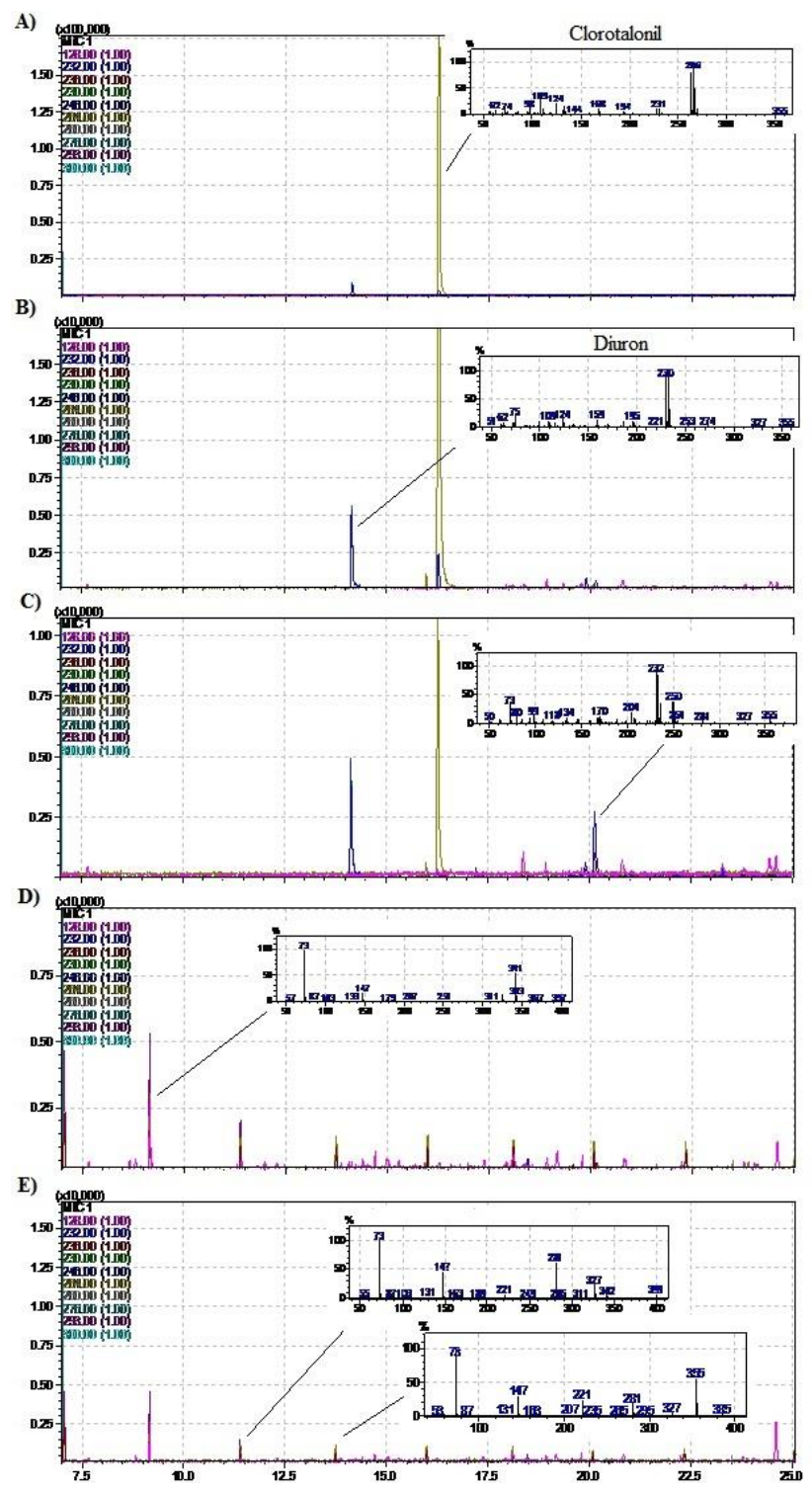

Figure 3 Chromatograms showing degradation of Chlorothalonil and the formation/disappearance of metabolites during the process at different times after A) 0 days, B) 4 days, C) 7 days, D) 21 days and E) 29 days for treatments 1 and 2 .

\section{Acknowledgments}

The authors are grateful for the financial support received by the Administrative Department of Science, Technology and Innovation "Francisco José de Caldas" - COLCIENCIAS to carry out this research, which was developed around the project INVEMAR/COLCIENCIAS No. 2105-40520261,"Use of native microorganisms from the Colombian Caribbean for bioremediation of coastal areas contaminated with pesticides". 


\section{References}

1] Colombian Agricultural Institute. 1996. "Pesticide Marketing: Import, Production, Sales and Exports". ICA, Agricultural Inputs Division. Produmedios. First edition. Bogotá. 56p.

[2] B. Singh, A. Walker y D. Wright. 2002. "Degradation of chlorpyrifos, fenamiphos, and chlorothalonil alone and in combination and their effects on soil microbial activity". Environ. Toxicol. and Chem., 21(12): 2600-2605.

[3] G. Bending, M. Rodríguez-Cruz y D. Lincoln. 2007. "Fungicide impacts on microbial communities in soils with contrasting management histories". Chemosphere, 69: 82-88

[4] EPA - Environmental Protection Agency, 1999. "Chlorothalonil registration eligibility decision (RED)2, EPA738-R-99-004, Washington, DC

[5] R. Sherrard, C. Murray-Gulde, J. J. Rodgers y Y. Shah. 2003. "Comparative toxicity of chlorothalonil: Ceriodaphnia dubia and Pimephales promelas". Ecotox. Environ. Safe., 56:327-333.

[6] P. Y. Caux, R.A. Kent, G.T. Fan y G. L. Stephenson. 1996 "Environmental fate and effects of chlorothalonil: a Canadian perspective". Crit. Rev. Environ. Sci. Technol., 26: 45-93.

[7] A. Draper, P. Cullinan, C. Campbell, M. Jones y A.N. Taylor. 2003. "Occupational asthma from fungicides fluazinam and chlorothalonil". Occup. Environ. Med., 60: 76-77.

[8] S. Humbert, S., M. Margni, R. Charles, O.M. Torres-Salazar, A.L. Quiro's y O. Jolliet. 2007. "Toxicity assessment of the main pesticides used in Costa Rica". Agric. Ecosyst. Environ., 118: 183190.

[9] Y. Dua, A. Singh, N. Sethunathan y A. Jahri. 2002. "Biotechnology and bioremediation success and limitations". Appl. Microbiol. Biotechnol., 59: 143-152.

[10] D. Sylvia, J. Fuhrmann, P. Hartel y D. Zuberer. 1998. "Principles and applications of soil microbiology". Editorial Prentice-Hall, Inc. New Jersey-USA. 469-479p.

[11] C. Kaplan y C. Kitts. 2004. "Bacterial succession in a petroleum land treatment unit". Applied and Environ. Microbiol., 70(3):1777-1786.

[12] K. Van Gestel, J. Mergaert, J. Swing, J. Coosemans y J. Ryckeboer 2003. "Bioremediation of diesel oil contaminated soil by composting with biowaste". Environ. Pollut., 125: 361-368.

[13] M. Van Eeden, H. C. Potgieter y A.M. Van der Walt, 2000 "Microbial degradation of chlorothalonil in agricultural soil: a laboratory investigation". Environ. Toxicol., 15: 533-539.

[14] J. B. Regitano, V.L. Tornisielo, A. Lavorenti y R. S. Pacovsky, 2001. "Transformation pathways of C-14-chlorothalonil in tropical soils". Arch. Environ. Contam. Toxicol., 40, 295-302.

[15] L. E. Castillo, C. Ruepert y E. Solis, 2000. "Pesticide residues in the aquatic environment of banana plantation areas in the North Atlantic zone of Costa Rica". Environ. Toxicol. Chem., 19: 1942-1950.

16] J. M. Betancourt-Portela, L. F. Espinosa, and L. A. Echeverri. 2009. "Pesticide evaluation in waters and sediments of the Colombian Caribbean". COLACMAR- Cuba 2009. Havana, 282p

[17] EPA- Environmental Protection Agency, 1996. "Chlorinated herbicides by GC using methylation or pentafluorobenzylation derivatization", Washington, DC.

[18] A. Chaves, D. Shea, y W. G. Cope. 2007." Environmental fate of chlorothalonil in a Costa Rican banana plantation". Chemosphere, 69: $1166-1174$.

[19] ANDI - Chamber of Industry for Crop Protection. 2000. "Proceedings of the Second International Symposium on the Science of Registration of Crop Protection Products". National University of Colombia. Bogotá. 140p.

[20] J. M. Betancourt-Portela, P.A. Bautista, J.P. Parra, S. Narváez and J.O. Sánchez. 2010." Final report of the project: Use of microorganisms native to the Colombian Caribbean for bioremediation of coastal areas contaminated with pesticides". Colciencias - Invemar, Code: 2105-405-2026. Santa Marta. 90p.

[21] M. L. Gómez, R. Nuñez, J. Dussásn, C. Hurtado, R. Casanova, J. Lozano, N. Campos, B. Marín, S. Narváez, R. Ruíz, V. Reyes and G. Cortés. 2005. "Final report. Selection and application of native marine bacteria with the capacity to degrade persistent organic compounds (POPs) in the Colombian Pacific and Caribbean". COLCIENCIAS contract 224-2003.

[22] M. L. Gómez, L. Vivas, R. Ruíz, V. Reyes and C. Hurtado. 2006. "Native marine bacteria that degrade persistent organic compounds in Colombia." Institute of Marine and Coastal Research INVEMAR- Santa Marta. Special Publications Series No. 19. 32p.

[23] S. Pakala, G. Purushotham, A. Basha, R. Kumar, R. Baru, M. Yanamandra, M. Merrick y D. Siddavattan. 2006. "Biodegradation of methy parathion and p-nitrophenol: evidence for the presence of a p-nitrophenol 2-hydroxylase in a gram-negative Serratia sp. Strain DS001”. Appl. Microbiol. Biotechnol., 73(6):1452-1462.

[24] J. Ledeberg y E. Ledeberg. 1952. Replica plating and indirect selection of bacterial mutants. J. Bact., 63(3): 399-406.

[25] M. Rani, K. Lakshmi, P. Devi, R. Madhuri, S. Aruna, K. Jyothi, G. Narasimha y K. Venkateswarlu. 2008. "Isolation and characterization of a chlorpyrifos degrading bacterium from agricultural soil and its growth response". Afr. J. Microbiol. Res., 2: 26-31.

[26] N. Rocas y J. Siqueira. 2005. "Species-directed 16S rRNA gene nested PCR detection of Olsenella species in association with endodontic diseases". Lett. Appl. Microbiol. 41: 12-16

[27] S. Altschul,, T. L. Madden, A. A. Schaffer, J. Zhang, Z. Zhang, W. Miller, y D. J. Lipman. 1997. "Gapped BLAST and PSI-BLAST: a new generation of protein database search programs". Nucl. Acids Res. 25:3389-3402.

[28] V. Granados, V. and D. Rodríguez. 2007. "Evaluation of a microbial inoculant in the composting process in flower culture". Degree work. Pontifical Javeriana University. Bogotá. 130p.

[29] INFOSTAT, 2010. Statistical software. Available at: http://www.infostat.com.ar.

[30] UNEP. 2008. "Guide for the sampling, preparation and analysis of organic contaminants in environmental samples (water, soil/sediment and biota)". GEF-REPCar Project Coastal Monitoring Program Manual. UNEP Caribbean Environment Programme. Kingston. 121p.

[31] M. Vidali. 2001. "Bioremediation. An overview". Pure Appl. Chem., 73: 1163-1172.

[32] J. Eweis, S. Ergas, D. Chang and E. Schroeder. 1999. "Bioremediation principles: treatments for the decontamination of soil and groundwater by biological and physical-chemical processes". McGraw-Hill. Madrid. 327 p.

[33] J. López and J. López. 1978. "The diagnosis of soils and plants (field and laboratory methods)". 3 ed. Mundi-Prensa. Madrid. 337p.

[34] IGAC, 1990. "General study of soils, for agricultural purposes, of the middle and lower basins of the Bogota River and surrounding municipalities (Department of Cundinamarca)". Bogotá. Printing IGAC. T1. 146p.

[35] T. L. Potter, R.D. Wauchope y A.K. Culbreath. 2001. "Accumulation and decay of chlorothalonil and selected metabolites in surface soil following foliar application to peanuts". Environ. Sci. Technol., 35 2634-2639.

[36] J. Muller, S. Duquesne, J. Ng, G. Shaw, K. Krrishnamohan, K. Manonman, M. Hodge y G.K. Eaglesham. 2000. "Pesticides in sediments from Queensland irrigation channels and drains". Mar. Poll. Bull., 41(7-12): 294-301.

[37] P.E. Davies. 1988. "Disappearance rates of chlorothalonil (TCIN) in the aquatic environment”. Bull. Environ. Contam. Toxicol. 40, 405409.

[38] A. Chaves, D. Shea y D. Danehower. 2008. "Analysis of chlorothalonil and degradation products in soil and water by GC/MS and LC/MS". Chemosphere, 71: 629-638. 